\title{
Corporate Social Responsibility and Accounting Restatement: Evidence from Pakistan
}

\author{
Shehzad Mehmood* \\ Lyallpur Business School, Government College University, Faisalabad, Pakistan \\ Rufia Saeed \\ Department of Commerce, Government College Women University, Faisalabad, Pakistan
}

Farhan Khan

Lyallpur Business School, Government College University, Faisalabad, Pakistan

Muhammad Irfan

Department of Management Sciences, Riphah International University, Faisalabad, Pakistan

\begin{abstract}
The research is financed by Asian Development Bank. No. 2006-A171(Sponsoring information)
Abstract

The study aims to analyze the relationship between corporate social responsibility and financial restatements. The study is conducted to check whether a CSR firm has to make less financial restatement. For this purpose, a sample of 150 non-financial firms are selected over the period of 2011-2018. The data are gathered from annual reports of these firms. Results of Logit regression analysis shows that CSR and financial statements are not significantly related with each other.
\end{abstract}

Keywords: Corporate Social Responsibility, Financial Restatements, Logit Regression

DOI: $10.7176 / \mathrm{JPID} / 53-02$

Publication date:March $31^{\text {st }} 2020$

\section{Introduction}

Autonomous affirmation of Corporate social responsibility (CSR) reports has turned into typical venture option of about $66 \%$ of the biggest 250 worldwide organizations with CSR reports freely guaranteed (KPMG, 2015). Interest in CSR confirmation is operated by necessity to persuade partners that company is properly dealing with natural and social dangers (Simnett et al., 2009). CSR affirmation seems, by all accounts, persuasive in this regard it decreases companies' expense of major and lessens examiner gauge blunders and scattering, particularly when bookkeeping firms gives the confirmation (Casey \& Grenier 2014). However, there is just inadequate observational proof on how CSR affirmation accomplishes these useful of capital market. Do capital market members just have extra trust in firms' accounted for CSR execution because of the CSR affirmation report or detailing additionally of superior value? Moreover, if broadcasting is in superior condition, define the competitive points of interest of accountant's in improving reporting quality?

This investigation utilizes remarkable making of repetitions of CSR reports to reveal insight into vital inquiries. Past examinations on inside CSR correspondence exhibit that internal correspondence is the most used channel, which includes the noteworthiness credited to CSR correspondence for inward accomplices (Birth et al., 2009). Another perspective is the way inside CSR correspondence impacts inside accomplices as internal accomplices expect a key employment in CSR, being advocates for associations' CSR programs (Morsing, 2006; Du et al., 2007; Coombs 2012). These specific conditions have been inspected by a couple of specialists who have recognized the openings among made and making countries when CSR is completed (Moon, Matten \& Moon 2004). At the point when an association's past announced monetary outcomes contain blunders, there is the need to rehash the money related explanations.

One case of a money related rehashing by a Canadian firm is Nortel Networks Corporation. On October 23, 2003, Nortel reported that it expected to rehash its monetary outcomes for 2000, 2001 and 2002 and the first and second quarters of 2003, because of its exhaustive resource and risk audit. Classic economists believe that sole responsibility of the company is to add financial worth to its Shareholders (Friedman, 1970). According to this opinion, the main goal of most firms, particularly in the nonpublic sector, it is increasing earning. Firms can rehash their money related articulations for reasons, for example, suspended tasks, stock parts, merger and acquisitions, changes in revealing cash or changes in bookkeeping standards. These sorts of repetitions speak to ordinary corporate exercises and ought not to have any material effect on firm an incentive because of bookkeeping abnormality. In this postulation, we just investigation the money related repetitions because of bookkeeping inconsistencies as indicated by the meaning of the (Abel et al., 1976) i.e., "bookkeeping anomaly is an occasion in which an organization repeats its monetary explanations since they were not reasonably displayed as per sound accounting guidelines (GAAP). This would incorporate material blunders and extortion". 
From Pakistan point of view there are domestic and foreign organizations in Pakistan who are functioning to encourage CSR for the benefits of customers and companies. In Pakistan, the CSR concept is at preliminary stages and not reached at maturity level, whereas not only corporation top management but the common public get conscious of their duties and responsibilities towards the common liabilities. Within spending of time and constancy the fiscal growth CSR will take a growth in the economy. In Pakistan many companies have started CSR activities at the vital level and awareness about CSR has been reported increasing during last ten years.

Anyhow, the purpose of present study is to examine the relationship between CSR and financial position of different sectors in Pakistan like cement sectors etc. There are various situations arise in the economy in which demand \& supply increase or decrease according the situation and the demand of the people in the economy. Such as cement demand rise at the local marketplace due to various dynamics such as floods and renovation after earthquake in Pakistan. Due to the CSR and organization development in cement industry, it is meaningful which affirmative influence on its investors.

As indicated by our insight, there is no earlier examination to utilize the Pakistani information to research the impact CSR on the bookkeeping restatement. The points of this investigation is two-crease as to quantify and increment the mindfulness degrees of CSR practices and announcing among Pakistanis companies. An audit approach is received utilizing the orders of (Abel et al., 1976) for the procedures in bookkeeping research. The principle constraint of these examinations is that the examples dissected incorporate exclusively the recorded no money related or budgetary organizations.

\section{Literature Review and Development of Hypothesis}

Setiawan (2011) conducted a study on the CSR and financial performance of Indonesian bonds and concluded the panel's assessment that social responsibility has a positive impact on the financial performance of sample companies. The impact of Jordan's industrial enterprises on CSR and profitability was further studied in order to illustrate the positive connection between CSR and profitability of selected companies in this study. Similarly, Mwangi \& Jerotich (2013) have examined the social and financial responsibility relationship in Manufacturing, Building and Ally companies in the Nairobi Securities Exchange between 2001 and 2011. The analysis results showed that a positive but insignificant connection between CSR and financial performance.

Kiran, Kakahel \& Shaheen (2015) examined the influence of financial performance on CSR by selecting ten petroleum-gas companies of Pakistan from 2006 to 2013. Findings revealed that the relationship between social liability and net profit margin is positive, but the relationship between social responsibility and total assets is negative. At the same time, the relationship between the company and social responsibility is negative. Overall, there is little impact on corporate profitability of the CSR activities.

Coffey \& Wang (1998) indicated that the best predictor for improving company social performance was good corporate governance. They revealed that management and society have a good relationship to understand corporate and corporate responsibility. Nelling \& Webb (2009) examined the connection between CSR and financial performance and mentioned the strong link between CSR and financial performance. Cheruiyot (2010) investigated the association between CSR and financial performance by using 47 Nairobi-based companies as a sample and concluded that the social responsibilities and financial performance of corporations have a significant relationship in terms of the return on equity, asset return and return on sales.

Mutuku (2005) concluded that CSR and money-related achievements are unrelated, making corporate social and budgetary responsibilities more ambitious in this study. The purpose of this study was to explore the application of sector-specific funds in Pakistan to the impact of CSR and currency performance. The results of the written study in Pakistan are another big, negative and random mix. Ali et al (2010) reported that the CSR of company is depending on various rating aspects. They consider that women's participation in the company could also enhance the reputation of companies. They describe that the image of the company in companies was a valuable factor when the men and women worked together

Dechow et al (2010) found the affirmative link between CSR and corporate performance. The mediation effect is also concluded for the performance of the company and the CSR services. The study recommended that enterprise organizations should take initiative in order to promote a social good apart from their belonging to individual concerns to comply with the relevant adjustments.

Srinivasan et al (2013) examined the impact of reviewers feature on financial reiterating by using the data of 130 firms that were listed in Tehran stock exchange. In this examination overseer features are audit firm size and commentator turnover and opinion. Research result exhibit that there is negative and centrality association between analyst turnover and firm size with reiterating figures. In like manner, the results show that there isn't any colossal association between evaluator appraisals with repeating figures.

Delmas \& Toffel (2008) inquired about the association among culture and CSR it has been used it, while constantly keeping a fundamental identity on this theory. His revelations reveal that the freedom/participation and power evacuate estimations affect CSR regards generally, and because of Brazil affect them quite which should incite a higher consideration in C.S. 
Du et al (2007) examined that how much an association recognizes benefits by its CSR activities can be coordinated by different plausibility factors, where the most basic of these are traits of the association, for instance, the association's reputation, and the enterprise which it works in such characteristics will in any case be slighted at this stage to help a broader audit of potential points of interest.

$\mathrm{H}_{1}$ : CSR firms are less inclined to have financial restatements.

\section{Data and Methodology}

The study explores that weather the CSR firms are less inclined to have financial restatements and fraud related financial restatements or not. The sample of the study consists of CSR ratings of 150 organizations that are registered with SECP. The data cover the period of 2011-2018 and are extracted from the annual reports of selected organizations. The study uses ER explained variables while CSR is used as explanatory variables. This study also uses FS, MB, LEV, ROA, NEG_ROA, AR_INV as control variables. The description and measurement of study variables are shown in Table 1.

Table1: Description of Variables

\begin{tabular}{|c|l|l|}
\hline \multicolumn{2}{|c|}{ Variables } & \multicolumn{1}{c|}{ Description } \\
\hline & $\begin{array}{l}\text { A restatement is proof that at least one budget lineup for an organization has } \\
\text { been reviewed to fix the error. Restatement is important to resolve past } \\
\text { variable } \\
\text { interpretations that involve "significant" errors. There are three types of } \\
\text { restatement variables that are: 1. lower reported net income that leads to } \\
\text { lower reported net. 2. Revenue statement that involve revenue of firm. 3. } \\
\text { Fraud statement that leads to an allegation of fraud or an investigation by } \\
\text { SECP }\end{array}$ \\
\hline Explanatory & CSR & $\begin{array}{l}\text { Net score of CSR rating, measured as total strengths minus total concerns, } \\
\text { based on six social rating categories of PBS Education, Health, Population } \\
\text { welfare, Housing, water supply and sanitation }\end{array}$ \\
\hline
\end{tabular}

\subsection{Econometric Model}

The study uses Logistic regression for estimating the results. Following model are used to analyze the effect of CSR on restatement.

ERit $=0$ if ERit $=\alpha 0+\alpha 1(\mathrm{CSR})$ it $+\varepsilon$ it $\leq 0$

ERit $=1$ if ERit $=\alpha 0+\alpha 1(\mathrm{CSR})$ it $+\varepsilon$ it $>0$

Where: ERit $=$ an indicator variable which is equal to one if a firm I restates its financial statements at least once in a given year $t$, and zero otherwise (Kothari, Leone et al. 2005)

\section{Results and Discussions}

4.1 Descriptive Statistics and Correlation Analysis

Table 2 shows the results about the descriptive statistics and Correlation analysis. In this table for the observations of 1200 we get the mean value for the restatement is $(0.275)$. The max value for the restatement is 1 with minimum value of 0 . And the standard deviation for the restatement is (0.446). The mean value for the CSR is $(0.251)$ as it has the maximum value for the CSR is $(0.584)$ and minimum value of 0 . The standard deviation for the CSR is (0.182). Moreover, the first column shows co relation between the CSR and restatement is very weak as it has value of (0.0143).

Table 2: Descriptive Statistics \& Correlation Analysis

\begin{tabular}{|l|c|c|c|c|c|c|c|}
\hline Variables & Restmt & CSR & Obsv. & Mean & SD & Min & Max \\
\hline Restmt & 1 & -- & 1200 & 0.275 & 0.4467 & 0 & 1 \\
\hline CSR & 0.0143 & 1 & 1200 & 0.251 & 0.182 & 0 & 0.584 \\
\hline
\end{tabular}

\subsection{Logistic Regression}

To see our speculations, we used a logit regression study of the Stata. If the dependent variable is dichotomous (double), the strategic recurrence is performed by a suitable recurrence study. As with all repeatability profiles, the repeatability calculation is an existing study. The strategic iteration is used to describe information and to clarify the relationship between dependent variable pairs and at least one free, intended, temporary, or reporting factor. The dependent variable should be dichotomous in nature (e.g. close, not missing). There should be no specificity in the data, which can be estimated by converting the infinite index to a standardized result, and which can be moved to the requirement 3.29 or higher instead of 3.29. There should not be a high correlation between the hands (multicollinearity). This can be seen in the structure of the link between tags. (Van der Laan Smith et al., 2005) suggest that the assumption is satisfied because the knowledge factor of the free factor is less than 0.90 . At the point of convergence of the calculated repeatability test is the likelihood probability of the logarithm of the 
event. The table shows the results of the logistic regression models telling the odds of restatements using various items. We specify the model using an indicator dependent variable as restatements.

The model tells us that the restatement indicator as dependent variable regardless of its nature. Results shows that CSR and restatement is not significantly associated with each other. This shows that there is no affirmative CSR measure are able to explain the chance of restatement. These results are similar to the (Lord \& Richard, 2007) in which the CSR enterprises are unlikely to be affected by SEC actions.

The main model tests give associations with CSR activities. It can be so Ordinary factors can lead to a reduction in the likelihood of CSR activities and revisions.

Table 3: Logit Regression

\begin{tabular}{|l|c|c|c|c|c|c|}
\hline Restmt & Odd. Ratios & SE & $\mathbf{Z}$ & P $>\mathbf{Z}$ & \multicolumn{2}{c|}{ [95\% Conf. int] } \\
\hline CSR & 1.192 & 0.421 & 0.50 & 0.619 & 0.595 & 2.385 \\
\hline Cons & 0.362 & 0.040 & -9.14 & 0.000 & 0.2919 & 0.450 \\
\hline LR chi (2)1 & \multicolumn{7}{|c|}{0.25} \\
\hline Prob $>$ chi2 & \multicolumn{7}{|c|}{-70193.679} \\
\hline Log likelihood & \multicolumn{7}{|c|}{-705} \\
\hline
\end{tabular}

\section{Conclusions}

CSR is the process with which companies manages their business to make an effective positive impact on the economy. It is about doing core business correctly and ethically. As in case of Pakistan, Pakistan is a developing country due to which it still lacks in CSR practice. There are some firms in Pakistan who are trying to take lead in this matter but it is still not enough to get in line with the firms of developed countries. As it is seen the more a CSR firm the more it gains trust from the stakeholders because people generally believe that this firm is in their betterment. Keeping in view, we made our objective of this study is to check if a CSR firm less restate its financial statement and a do a CSR firm has to less to make fraud related financial restatement. For this purpose, we collected our data of 150 non-financial firms for the period of 2009 to 2016 . This makes 1200 observations for study in our research purpose. All the required data is collected from the annual reports of the 150 organizations. We gathered our restatement sample from the annual reports. It is needed that all the restatements have data about restatement reporting and peculiar reporting period linked with restatement. We pursue earlier literature to erase restatement involving using of new accounting proclamation or clarification Technical revisions do not associate distortions in the original repository Merger, stop operations, GAAP principles change and advertising Potential revisions will not lead to recovery to check the effect of restatement, we made an indicator variable with the name of restatement.

On the bases of previous studies about accounting restatement we used the logit regression analysis to get the relationship among CSR and Accounting restatement. Results shows that CSR and restatement is not significantly associated with each other. This shows that there is no affirmative CSR measure are able to explain the chance of restatement. These results are quite similar to the previous studies such as (Lord \& Richard, 2007) in which CSR Business were affected by SEC actions.

This study has some limitations firstly is this study covers only non-financial sector of the Pakistan economy, and not financial sector of the Pakistan economy. Due to limited time period the data sample covers only limited part of firm year and does not expand the time period. Moreover, this study covers financial statement disclosure and the uncertainty in firm motivation about CSR activities

CSR is vast brand of research in case of Pakistan. One can make research on different perspective of the Pakistani economy using the CSR. As you can check that most of the economic parts are unexplored in the matter of CSR. For the purpose of future study one can check the effect of restatement and CSR on the financial sector of the economy i.e. banks and money lending institutions. Moreover, one can expand the data set time period for the given interval of time.

\section{References}

Abel, R. M., et al. (1976). "Etiology, incidence, and prognosis of renal failure following cardiac operations. Results of a prospective analysis of 500 consecutive patients." The Journal of thoracic and cardiovascular surgery 71(3): 323-333.

Ali, I., Rehman, K. U., Yilmaz, A. K., Nazir, S., \& Ali, J. F. (2010). "Effects of CSR on consumer retention in the cellular industry of Pakistan. African." Journal of Enterprise Management, 4(4): 475-485.

Birth, G., et al. (2009) Communicating CSR: Practices among Switzerland's top 300 companie

Casey, R. J. and J. H. Grenier (2014). "Understanding and contributing to the enigma of CSR (CSR) assurance in the United States. Auditing." A Journal of Practice \& Theory 34(1): 97-130.

Cheruiyot, F., K. (2010). The relationship between CSR and financial performance of companies listed at the Nairobi Stocks Exchange, University of Nairobi. Unpublished MBA Thesis. 
Coffey, B. S., \& Wang, J. (1998). ". Board diversity and managerial control as predictors of corporate social performance. ." Journal of enterprise ethics 17(14): 1595-1603.

Coombs, T. (2012). Coombs, W.T. \& Holladay, S.J. (2012). The paracrisis: The challenges created by publicity managing crisis prevention. Public Relations Review, 38(3), 408-415.

Dechow, P. M., et al. (2010). "Fair value accounting and gains from asset securitizations:" A convenient earnings management tool with compensation side-benefits. Journal of accounting and economics 49(1-2): 2-25.

Delmas, M. A., \& Toffel, M. W. ((2008).). " Organization responses to environmental demands: Opening the black box. ." Strategic Management Journal, 29, : 1027- 1055.

Du, S., et al. (2007). "Reaping Relational Rewards from CSR: The Role of Competitive Positioning." International Journal of Research in Marketing 24: 224-241.

Du, S., et al. (2007). "Reaping Relational Rewards from CSR: The Role of Competitive Positioning." International Journal of Research in Marketing 24: 224-241.

Friedman, M. ((1970, September 13). ). The social responsibility of business is to increase its profits., The New York Times Magazine.

Kiran, S., Kakakhel, S. J., \& Shaheen, F. (2015). "CSR and firm profitability: A case of oil and gas sector of Pakistan. ." City University Research Journal, 5(1), 110-119.

Lord, H., \& Richard, W. (2007). "'Making Good Enterprise Sense" The World Enterprise Council for Sustainable Development.".

Moon, D. S. E. The Oxford handbook of CSR O. U. Press. New York, NY:

Morsing, M. (2006). Strategic CSR Communication: Telling Others How Good You Are: 238-246.

Mutuku, K. (2005). The relationship between CSR \& Financial performance, A case of Publicly Quoted Companies in Kenya. U. M. Thesis. University of Nairob

Mwangi, C. I., \& Jerotich, O. J. (2013). "The relationship between CSR practices and financial performance of firms in the manufacturing, construction and allied sector of the Nairobi Securities Exchange." International Journal of Business, Humanities and Technology

Nelling, E., \& Webb, E. (2009). " CSR and financial performance: the "virtuous circle" revisited. ." Review of Quantitative Finance and Accounting, 32(2): 197-209

Setiawan, M. D. (2011). "The relationship between CSR and firm financial performance: evidence from the firms listed in LQ45 of the Indonesian Stock Exchange Market. ." European Journal of Social Sciences 23(2): 288293

Simnett, R., et al. (2009). "Assurance on sustainability reports: An international comparison." The accounting review, 84(3): 937-967.

Srinivasan, J., et al. (2013). "The draft genome and transcriptome of Panagrellusredivivus are shaped by the harsh demands of a free-living lifestyle." Genetics, genetics 11. 